\title{
Judical Review on The Authority of Subdistrict Head as A Temporary Land Deed Officials in The Making of Deed in Bojong Subdistrict, Tegal Regency
}

\begin{abstract}
Muhammad Muamal ${ }^{1}$, Khanafi ${ }^{2}$ and Amin Purnawan ${ }^{3}$
Abstract. The Sub-district head is appointed as temporary PPAT based on the provisions of the Act. It is due to there is not enough PPAT in the government area, so the government gives authority to the Sub-district head to serve the community in making deeds related to the transfer of Land Rights. In reality, not all sub-district heads are able to carry out their duties and authority. The constraints are due to the lack of Sub-district head knowledge about the duties and authority as PPAT, the number of Sub-district head duties in the government field which cause the affairs of the process of transferring rights to land are neglected and are often delegated to sub-district staff. Furthermore, the PPAT Deed Forms should not be used again since the enactment of the Regulations of the Republic of Indonesia National Land Number 8 year 2012. However, in reality many temporary PPAT or Sub-district heads still use the old forms which are no longer specified in the applicable Regulations. The deed made must be an Authentic Deed as stipulated in Article 1868 of the Civil Code concerning the Authentic Deed, namely a deed which is in the form prescribed by law, made by or before the public officials where the deed is made. On the other hand, the position as a PPAT must be in accordance with PP Number 37 year 1998 concerning the Regulation of the Position of the Land Deed Officials Keywords: Sub-district head Authority; Temporary PPAT; deed
\end{abstract}

\section{Introduction}

Problems related to land from day to day show an increasingly complex tendency. In order to establish legal certainty of land rights, land registration is required. This land registration problem has been regulated by the government, namely with the issuance of Government Regulation Number 24 year 1997 concerning Land registration which replaces Government Regulation Number 10 year $1961^{4}$. It provides specific restrictions and provisions concerning land registration. This law is expected in general national development equity and the issue of land registration in particular can be implemented and yield maximum results. The government has the authority to regulate the use of land and then appoint an agency or body authorized for that. In land registration, the government appoints the National Land Agency to implement it, as referred to in

\footnotetext{
1 Master of Notary's Student, Faculty of Law, Universitas Islam Sultan Agung email quthbieransi@gmail.com

Students of Master of Law, Faculty of Law, Universitas Islam Sultan Agung email khanafihaji@gmail.com

${ }^{3}$ Lecturer of Faculty of Law UNISSULA

4 The Government Regulation of the Republic of Indonesia No 24 Year 1997 on Land Registration
} 
Article 5 of Government Regulation Number 24 year 1997 concerning land registration, it states that: "Land registration is organized by the National Land Agency". Furthermore, in Article 6 paragraph (2) it is stated: "In carrying out land registration, the Head of the land office is assisted by the Land Deed Officials (PPAT) and other officials assigned to carry out certain activities according to this Government Regulation and the relevant Laws and Regulations".

In accordance with the provisions of Article 7 of Government Regulation Number: 24 year 1997 concerning Land Registration ${ }^{5}$, Government Regulation Number: 3 year 1998 concerning Regulation of the Position of Land Deed Officials. Then Article 1 paragraph (1) PP No. 37 year 1998 states that "Land Deed Officials (PPAT) are Public Officers who are given the authority to make authentic deeds regarding certain legal acts concerning land rights or ownership rights in flats".

In connection with the Sub-district head as the Land Deed Officials, hereinafter referred to as PPAT, it must be realized that the assignment and authority are temporary because of ex officio as Local Head. The risk and responsibility of the Subdistrict head as PPAT is greater than a Notary/PPAT. It is due the accountable for a decision or legal action taken in the determination of a deed, the sub-district head can be prosecuted in the State Administrative Court (PTUN) or can also be subject to a sentence of office from his superiors. The region must be aware of the conditions and problems in its territory, especially land issues (land status, land transfer, plan of use and the usage).

Theoretically, the implementation of the Sub-district head Position as temporary PPAT has the same authority as PPAT in general. However, in practice in the field, especially in the making of Land Deed, there are problems related to the authority of the Subdistrict head as PPAT. The problem arises because of the overlap of duties and responsibilities as government officials and as a temporary land deed official. These two functions cannot run maximally by the Sub-district head. Moreover the sub-district head does not have special expertise on land issues, at the end it affects the authenticity of the deed he made. The Authentic Deed should be made by or before an authorized official. However, there are many cases found that the Sub-district head as Temporary Land Deed Officials did not meet directly and read out his deed before the opponents, but was sufficiently represented by his staff in the Sub-district head. Whereas in Article 22 of the Government Regulation Number 37 year 1998 concerning the Regulation of the Position of the Land Deed Officials, it is stated that "the Land Deed must be read out/explained its contents to the parties in the presence of at least 2 (two) witnesses before being signed immediately by the parties, the witnesses and the notary ".

Besides, the deed is based on the Regulation of the Head of the National Land Agency of the Republic of Indonesia Number 8 year 2012 concerning amendments to the Regulation of the Minister of Agrarian Affairs/Head of the National Land Agency No. 3 year 1997 concerning the implementation provisions of Government Regulation No. 24 year 1997 concerning Land registration article 11 (b) which explained that the form of Land deed must be returned to the local Land Office no later than March 31, 2013. But

\footnotetext{
${ }^{5}$ Ibid,
} 
in reality many Temporary Land Deed Officials or Sub-district heads still use the old forms which are no longer specified in the applicable Regulations. This raises the question about the authenticity of the land deed made since it is made by not using the form or format specified in the above regulation.

Based on this background, it can be found problems about how the Sub-district head authority acting as temporary Land Deed Officials (PPAT) in the Making of Deeds in Bojong sub-district, Tegal Regency based on Government Regulation Number 37 year 1998 and how the Legality of the deed which is made by sub-district head without being read before the Parties in accordance with Article 1868 of the Civil Code concerning the Authentic Deed.

\section{Research Methods}

This journal was based on the Sociological Juridical approach. Juridical means that the approach in this study examined theories, concepts, legal principles and legislation relating to the position of the Sub-district head as the Land Deed Officials (PPAT) while in the making of the Land Deed. Sociologically means that in this study used methods of science and saw the reality in the field, especially in the implementation of Duties and Position of Sub-district head as Temporary PPAT.

The Types and sources of research data include primary legal material, namely data obtained directly from the respondent. In this case is the Head of Subdistrict as Temporary PPAT and the parties who conduct land transactions with Temporary PPAT evidence which is the source of the Legislation and related Implementation Regulations with PPAT and Authentic Deed. Secondary legal materials, namely data that has been presented obtained from institutions of research, such as the Head of the District Office in the form of the number of land rights transactions. Tertiary legal materials sourced from the Large Indonesian Dictionary and Legal Dictionary.

\section{Research Results and Discussion}

\subsection{Sub-district head Authority Acting as Temporary Land Deed Officials (PPAT) in the Making of Deed in Bojong District, Tegal Regency is based on Government Regulation Number 37 year 1998;}

According to Boedi Harsono, what is meant by PPAT is a position (ambt) in the arrangement of our National Agrarian Law, especially the law governing land registration. It can also be interpreted as "people" who served the position. Based on the understanding in PP No. 24 year 1997 and PP No. 37 year 1998, it can be concluded that, PPAT is a "public official". 6

According to Effendi Peranginangin, public officials are people who are appointed by the authorized institution with the task of serving the general public in certain fields of activity. Certain activities referred to above include making a Deed. ${ }^{7}$

\footnotetext{
${ }^{6}$ Boedi Harsono 2002 Hukum Agraria Indonesia Himpunan Peraturan-Peraturan Hukum Tanah Djambatan Jakarta page. 44

7 Effendi Peranginangin 1994 Hukum Agraria di Indonesia raja Grafindo Persada Jakarta page. 62
} 
Government Regulation Number 37 year 1998 concerning Land Deed Officials is a juridical basis for regulation of PPAT in Indonesia. In Article 1, it is stated that: "PPAT is a public official who is given the authority to make Authentic Deed concerning certain legal acts on Land Rights or Property Rights of Flats". PPAT as the official authorized to make the authentic deed of transfer of land rights is appointed and dismissed by the Minister of Agrarian/Land Affairs. All matters relating to the duties and authority of the PPAT are confirmed in Government Regulation Number 37 year 1998 on Regulation of the Land Deed Making Position which was set forth on March 5, 1998 (State Institute of 1998 Number 52, Supplement to the State Gazette Number 3746. This is reinforced by Government Regulation No 37 year 1998 concerning the Regulation of the Land Deed Making Official in Article 2 paragraph (1) which reads:

"PPAT is in charge of carrying out part of the land registration activities by making a deed as proof of certain legal actions regarding land rights or ownership rights of the Flats that will be used as a basis for registration of changes in land registration data resulting from the legal act". 8

From the results of field studies, the Head of Sub-district as a Temporary PPAT (Land Deed Officials) still holds a large role in the implementation of the transfer of Land Rights. Based on the results of a survey conducted in the Bojong Subdistrict, Tegal Regency, there are still many people who use the Sub-district head's services in carrying out legal actions related to land such as buying and selling, exchanging, granting, sharing rights together.

The above legal actions are indeed the authority of the Sub-district head as Temporary PPAT, the same as the Land Deed Officials (PPAT) in general, as referred to in Article 2 paragraph (2) Government Regulation Number 37 year 1998. It states that "Legal acts as referred to in paragraph (1) are as follows: buying and selling, exchanges, grants, income into the company (inbreng), sharing of joint rights, distribution of Right to Builds/Rights to Use on the land of the Right of Ownership, granting of Mortgage Rights, authorizing to give Mortgage Rights ".

The Sub-district head's authority as a temporary PPAT, especially in the Bojong subdistrict area, is along with 2 (two) Land Deed Officials (PPAT). The sub-district head still dominates in handling the Land Rights Transition issue. This is because the habits that have been running in the community, especially villages in Bojong Subdistrict since before the existence of a Notary/PPAT. They always submit the issue of the transfer of land rights to the Sub-district head, so that the Sub-district head also acts as a mediator in resolving land disputes. ${ }^{9}$

The community needs to know and understand the rule of law. In in every legal act committed by a General Officer, in this case is PPAT and the Sub-district head as PPAT, in the process of transferring land rights must be stated in the form of Authentic deed, which later gives legal certainty and legal protection to the parties that are interrelated. Thus, later on the Deed made by the Official in this case the Sub-district head can be used as a perfect proof of the Transition of Land Rights.

\footnotetext{
${ }^{8}$ Boedi Harsono Op.cit. page. 538-539.

${ }^{9}$ Interview result with subdistrict head of Bojong Bapak Muktarom S.IP on 6 June 2018
} 
Besides, the community also needs to know that in order to obtain a task or authority from the government, it is necessary to have expertise and education to show his/her capability in any fields. Hence, the community is expected to be more careful in choosing officials who will assist in the process of transferring land rights, so that they can run smoothly and have no potential a dispute arises in the future, especially with regard to the deed that was made by the official.

From the results of the research conducted, especially in the Bojong District, the Head of Subdistrict as temporary PPAT. The subdistrict head is not too focused on dealing with the issue of the Transition of Land Rights, because the issue in the field of government was quite time consuming. So that he mostly delegate his staff or people who have more experience in the field of land. Moreover, he does not pay attention to the risk in the future. As a result, if there is dispute in the future the subdistrict head will know nothing about the problems, whereas his signature is on the letter. Moreover, the subdistrict head can be asked his responsibility for something he knows nothing about.

The legal basis for the appointment of a Sub-district head as Temporary PPAT can be seen in Article 5 paragraph (3) of Government Regulation No. 37 year 1998 concerning the PPAT Position Regulation states that:

"To serve the community in making Land Deed in an area where there is less number of PPAT and to serve certain groups of people in the making of certain Land Deeds, the Minister can appoint the following officials as Temporary PPAT or special PPAT, Subdistrict head or Village Head to serve the deed regions that do not have enough PPAT, as Temporary PPAT ". ${ }^{10}$

If you understand carefully the article, it can be interpreted that if an area appears to have existed or is considered sufficient to have PPAT, then there is no need for the role and authority of the temporary PPAT. Because along with developments in the world of education, there are more graduates from universities that are qualified in the field of land and also many of them have been appointed as PPAT in almost every sub-district in Indonesia, especially in Java. So that it becomes a clear reason for the public to prioritize legal certainty and protection in carrying out legal actions concerning the transfer of land rights. In is done to avoid disputes in the future, namely by visiting a qualified official and expert in his field. If the field is a matter of transferring land rights, then the Notary/PPAT is the right choice because the Notary/PPAT clearly has the capacity. They have received special education related to the issue of Land Rights in Higher Education and also has an official permit from the authorized government so that the legality does not need to be questioned in carrying out its authority.

\subsection{Legality of the deed from the Temporary Land Deed Officials (PPAT) made by the Sub-district Head without being Read before the Parties in accordance with Article 1868 of the Civil Code concerning the Authentic Deed}

\footnotetext{
${ }^{10}$ A.A Mahendra 2001 Tugas dan Wewenang Jabatan PPAT Sementara Pustaka ilmu Jakarta page. 7
} 
Deeds made by PPAT/temporary PPAT are mostly in the form of descriptions or statement. The statements of the parties before Temporary PPAT/PPAT Officials, such as sale and purchase deeds, grant deeds, exchange certificates and other deeds that require the face to face with the official who will make requested certificate.

Regarding the condition that the deed must be made by a public official who has the authority to make a deed, it is affirmed in Article 4 paragraph 1 of Government Regulation Number 37 year 1998 which states: "PPAT is only authorized to make a deed regarding land rights or ownership rights over units of flats that located within its work area". So that a deed is made by an unauthorized official or does not meet the requirements as stipulated by law, then the deed is not an authentic deed, but has the evidentiary power as an underhand deed.

Temporary PPAT Deed is made as evidence. Its function is to ensure a legal event, with the aim of avoiding disputes. Therefore, the deed maker is expected that the deed does not contain formulations that can cause a dispute because it is incomplete and unclear. ${ }^{11}$

The Authentic Deed must fulfill the requirements of authenticity as determined by law, one of which must be made by or before an authorized official. In this case PPAT or temporary PPAT holds an important role in the context of fulfilling the authenticity of a letter or deed in order to have perfect evidentiary power. Based on Article 1 paragraph 1 of PP No. 37 year 1998, PPAT is a public official authorized to make authentic deeds concerning certain legal actions on land rights or Ownership Rights to Flats.

From the results of research carried out in the Bojong Subdistrict area, the Sub-district head as a temporary PPAT apparently did not directly meet with parties who intend to make a request for the transfer of Land Rights, especially what is often encountered is in the process of transferring land rights due to sale and purchase. The basis of the transfer of rights is to have a Sale and Purchase Deed (AJB) made by the Sub-district head as Temporary PPAT. The parties must face and meet directly with the Sub-district head as a Temporary PPAT by law. But it does not happen. The Sub-district head does not meet with the parties who should be listed in the Deed, but those who meet with the parties are only a staff member or an unofficially appointed person to take care of the process of making the Deed. So that the existing deed will not be read in front of the parties directly by the Sub-district head as a temporary PPAT, the signature from the Sub-district head as Temporary PPAT is considered enough.

This can result in a dispute arising in the future. If there is one of the parties listed in the Deed feel disadvantaged and sue to the Court on the deed that was made and signed by the Sub-district head as Temporary PPAT. Whereas it is clearly stated in the provisions of Article 22 of the Government Regulation Number 37 year 1998 concerning the Regulation of the Position of the Land Deed Officials stated that "the PPAT Deed must be read out/explained its contents to the parties and attended by at least 2 (two) witnesses before being signed immediately by parties, the witnesses and Notary ${ }^{12 " .}$ Besides, the temporary land deed also should be an Authentic Deed as

\footnotetext{
${ }^{11}$ Effendi Peranginangin 1987 Praktek Jual Beli Tanah Rajawali Pers Jakarta page. 26-27

${ }^{12}$ Pasal 22 PP Nomor 37 Tahun 1998 tentang Peraturan Jabatan Pejabat Pembuat Akta Tanah Penerbit Citra Umbara 2016 Bandung page. 138
} 
stated in Article 1868 of the Civil Code concerning the Authentic Deed, which is a deed in the form prescribed by law, made by or before the general employees in power for that place where the deed is made.

The validity of a deed is in the form determined by law (standard form) and made by and before the authorized officials. This is in line with the opinion of Philipus M. Hadjon, that the terms of an authentic deed include: ${ }^{13}$

- In a form determined by law (standard form); and

- Made by and before the authorized public official.

Therefore, based on the findings in the field, the Deed made by the Head of Subdistrict as temporary PPAT is in old form. In fact, the old form should no longer be used, as stipulated in the Regulation of the Head of the National Land Agency of the Republic of Indonesia Number 8 year 2012 concerning changes to Regulation of the Minister of Agrarian Affairs/Head of the National Land Agency Number 3 year 1997 concerning the implementation provisions of Government Regulation Number 24 year 1997 concerning Land registration article 11 (b) which states that the PPAT deed must be returned to the local Land Office by 31 March. Therefore, the Sub-district head deed as Temporary PPAT cannot prove its validity as an Authentic deed.

Besides, formally, the Sub-district head's deed was not made and read out before the Parties, because the Sub-district head did not meet directly with the parties, but was represented by his staff. Thus, the temporary deed has not been able to prove its validity as an authentic deed.

\section{Conclusion}

- Sub-district head authority as Temporary PPAT is the same as the PPAT/Notary Authority. The Head of the District who has been appointed as a Temporary PPAT can do Legal Acts related to Transition of land rights, they should always be guided by the Government Regulation of the Republic of Indonesia concerning the Regulation of Land Deed Officer No. 37 year 1998, namely in making a deed related to the transfer of land rights must know directly the parties facing to be able to express their intentions and objectives clearly. Therefore, the authority given as Temporary Land Deed Officials in making the deed can be carried out correctly and does not cause disputes on the parties in the future.

- Deeds made by the Sub-district head that do not fulfill the elements in Article 1868 of the Civil Code concerning the Authentic Deed, may cause the deed becomes underhand deed, so that it has the potential to cause problems in the future.

\section{References}

[1] Boedi Harsono 2002 Hukum Agraria Indonesia Himpunan Peraturan-Peraturan Hukum Tanah Djambatan Jakarta.

[2] Effendi Peranginangin 1994 Hukum Agraria di Indonesia raja Grafindo Persada Jakarta.

\footnotetext{
${ }^{13}$ Philipus M. Hadjon 2001 "Formulir Pendaftaran Tanah Bukan Akta Otentik" Post Surabaya page. 3
} 
[3] A.A Mahendra 2001 Tugas dan wewenang Jabatan PPAT Sementara Pustaka Ilmu Jakarta.

[4] Effendi Perangin 1987 Praktek Jual Beli Tanah Rajawali Pers Jakarta.

[5] Philipus M. Hadjon 2001 Formulir Pendaftaran Tanah Bukan Akta Autentik Post Surabaya.

[6] Kitab Undang-undang Hukum Perdata

[7] Peraturan Pemerintah (PP) Nomor 24 Tahun 1997 tentang Pendaftaran Tanah

[8] Peraturan Pemerintah (PP) Nomor 37 Tahun 1998 tentang Peraturan Jabatan Pejabat Pembuat Akta Tanah.

[9] Peraturan Menteri Agraria/Kepala Badan (PERKABAN) Pertanahan Nomor 8 tahun 2012 tentang Perubahan atas Peraturan Kepala Badan Pertanahan Nasional Republik Indonesia Nomor 3 Tahun 1997 tentang ketentuan pelaksanaan PP Nomor 24 Tahun 1997 tentang Pendaftaran Tanah 